\title{
Chapter Managing Indonesian
Haze: Complexities and
Challenges
}

\author{
Asit K. Biswas \\ Distinguished Visiting Professor, Lee Kuan Yew School of Public Policy, \\ National University of Singapore \\ prof.asit.k.biswas@gmail.com \\ Cecilia Tortajada \\ Senior Research Fellow, Institute of Water Policy, \\ Lee Kuan Yew School of Public Policy, National University of Singapore \\ cecilia.tortajada@nus.edu.sg
}

\section{Introduction}

Transboundary air pollution is not a new phenomenon. It has existed for centuries in one form or another. Causes for this pollution could be both natural and man-made. However, prior to 1960 , it was not a serious issue since population levels, urbanization rates and the extent of industrial and agricultural activities were rather low. Equally, prior to 1960, all types of environmental pollution were generally accepted by societies to be prices that had to be paid for economic progress. In addition, the health, economic and environmental costs of air, water and land pollution were neither properly known nor fully appreciated. Thus, if there was a conflict between economic growth and environmental pollution, it was routinely resolved in favor of economic growth.

The situation started to change around 1970 when many people in the industrialized world started to realize and appreciate the increasing costs of environmental pollution that had significantly adverse impacts on the human and the ecosystems health. The smog of the 1950s in major cities 
like London, Los Angeles and Tokyo made their inhabitants question if unfettered economic growth, at the cost of environmental deterioration, is a desirable long-term societal policy option. Shortly thereafter, a nascent environmental movement started. It began to gain momentum and flexed its muscles during the post-1970 period.

Transboundary air pollution first burst into global consciousness during the 1960s when some Swedish and Norwegian scientists noted that a large number of their lakes were showing increasing acidity. This resulted in a steady increase in fish kills and serious negative impacts on many other species. Aquatic biodiversity was declining. Forests were also adversely affected.

The culprit was found to be acid rain whose sources were outside Scandinavia. Acid rain was being caused by sulfur dioxide and nitrogen oxides emitted by factories in the United Kingdom, West Germany and several East European countries which reacted in the atmosphere with the water droplets in the clouds. The net result was that rainfall in Sweden and Norway contained higher concentrations of nitric and sulfuric acids, which started to take its toll on aquatic and territorial ecosystems by acidifying lake waters.

During the late 1960s, Sweden tried very hard to convince the emitting countries of the problems they were causing in Scandinavia and attempted to persuade them to reduce their atmospheric emissions. Being unable to move bigger countries like the United Kingdom or Germany to reduce their emissions, Sweden offered to host the 1972 United Nations World Conference on the Human Environment in Stockholm. The hidden agenda behind this offer was to bring the problem of transboundary air pollution and the harm it was causing to Sweden and other Scandinavian countries to global attention.

This strategy succeeded in increasing the global awareness of this issue (Biswas and Tortajada, 2013) and also internationalizing and bringing it to a major United Nations forum. This Conference and subsequent efforts led to the adoption of the Convention on Long-range Transboundary Air Pollution in 1979 (UNECE, 1979). It entered into force in 1983. This has now been ratified by 53 members of the UN Economic Commission for Europe.

As a result of this legally binding treaty, collective efforts of the emissions of harmful air pollutants have been reduced by 40 to 80 percent since 1990. Sulphur emissions have declined very significantly. This meant that acid rain problems in Europe had been mostly consigned to the dustbin of history, and forests are healthier. 
Some 30 years later, transboundary smoke pollution became an important concern in most Southeast Asian countries, except for Myanmar and Laos, and some Pacific island areas like Guam, Palau and Northern Mariana Islands. They are affected by haze because of forest and vegetation clearance by fire, primarily in the Indonesian provinces of Sumatra and Kalimantan. This clearance is to ensure increasingly more and more land is available for expanding the area for palm oil cultivation to meet the burgeoning global demand.

The main difference between the Swedish and the Indonesian cases is that acid rain had very limited impact on the emitting countries like United Kingdom and Germany. In contrast, the Indonesian haze is having the most severe health, economic and environmental impact on the country from where it originates, as well as on its neighbors. Even then, it has proved to be an intractable problem to solve.

\section{Indonesian haze: Background to the problem}

Palm oil is not indigenous to Asia. The Portuguese first discovered palm oil in the 15th century in Africa. They found that the small farmers of West African rainforests used palm oil for soups and baking. Following this Portuguese discovery, palm oil gradually became an important provision for trading caravans and slave ships.

In an Asian context, the British administrators first introduced oil palm in the 1830 s to India. They planted some seedlings in the botanic garden of Kolkata. Trial commercial planting was started later in Kerala. They did not make much headway.

In Indonesia, oil palm first arrived in 1848, via Amsterdam. Like in India, four seedlings were planted in the botanic garden of Bogor. They were initially considered to be ornamental plants and were planted in tobacco estates and roadsides for beautification purposes.

Commercial plantation for palm oil in Indonesia started in 1911, in Sumatra, by a Belgian agronomist, Adrien Hallet. Hallet had interest in rubber plantations in the then Belgian Congo. In 1912, Henri Fauconnier, a Frenchman, bought some seedlings from Hallet. He established the first commercial plantation in Malaysia, at Tennamaram Estate, Selangor. Having failed at making a successful coffee plantation, Fauconnier thought he would have better luck with palm oil. 
After the Second World War, rubber plantations ran into severe headwinds because of rapidly falling demands. Large-scale plantation owners looked at crop diversification, and oil palm appeared to be a good potential alternative. An intensive agricultural research and breeding program was started in Malaysia to assess the economic feasibility of palm oil.

Because of good agro-climatic conditions, oil palm cultivation has always been a good prospect for Malaysia and Indonesia. However, it has had a rather checkered development history in Indonesia. Its development was in the doldrums after Indonesia's independence in 1945. Dutch plantation owners no longer received financial and political support from the colonial government. Some two decades later, in 1967, commercial plantations picked up some steam under its second President, Suharto. Investments were made through state-owned enterprises, with financial support from the World Bank.

During the 1980s, oil palm plantations received a major boost following a finding that these trees are pollinated by a tiny weevil, and not by wind, as previously thought. Introduction of these pollinating weevils in Malaysia and Indonesia dramatically reduced the cost of pollination which earlier was being done by human hands. In the 1980s, Malaysia became the world's largest producer of palm oil.

With an increasing global population and more and more people having steadily higher incomes, their dietary habits and requirements have changed as well. The global demand for edible oils and fats have steadily increased following the Second World War. With this ever increasing demand, global production of all types of oil seed crops have increased concomitantly as well.

Oil palm is the most efficient oilseed crop in the world. Its average oil yield per hectare is about 6-10 times that of soybean, sunflower or rapeseed (Figure 1). At present the most efficient oilseed farmers can get as much as 8 metric tons of oil per hectare. Thus, not surprisingly, even though oil palm accounts for less than $6 \%$ of total area in which ten of the world's most important major oil seed crops are cultivated, it accounts for nearly $32 \%$ of global oil and fat outputs.

Currently palm oil is Indonesia's second most successful agricultural product, after paddy rice. It is now by far the country's largest agricultural export earner, accounting for nearly $11 \%$ of the country's total export 


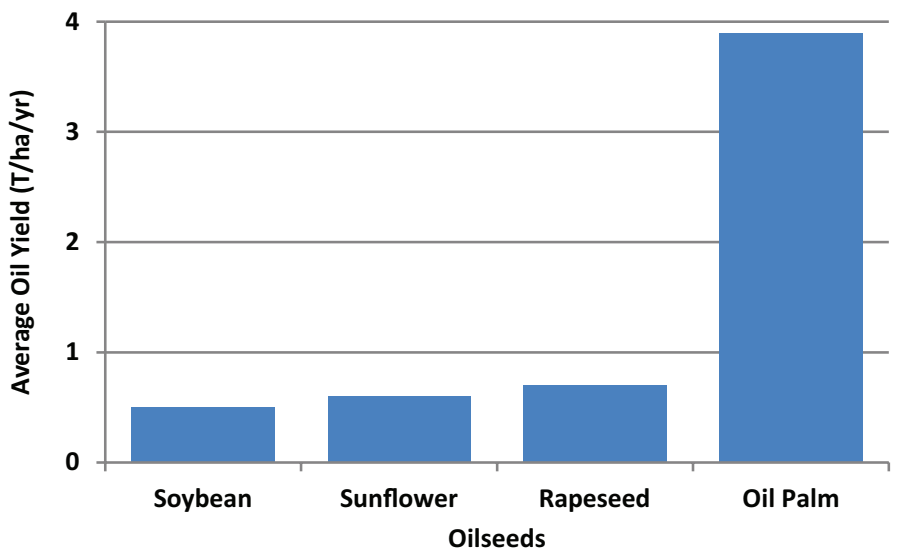

Figure 1. Average Yield of Oilseeds Crops

Source: Oil World (2013).

earnings. For the rural poor, it is a most important source of income and survival. In 2015, 54\% of the Indonesians lived in rural areas. Thus, oil palm cultivation has been one of the important pillars for economic development and poverty alleviation policy for the country in the recent decades.

Development of oil palm cultivation truly picked up steam when Susilo Bambang Yudhoyono was re-elected as the Indonesian President. In his inauguration speech in 2009, he expressed his determination to improve the country's welfare and reduce poverty. These objectives, he said, would be achieved through "economic development based on competitiveness of natural resources management and human resources development" (Jakarta Globe, http://jakartaglobe.beritasatu.com/archive/ sbys-inaugural-speech-the-text/).

President Yudhoyono's plan led Indonesia to become the largest palm oil producer country by far in the world. In 2016, its annual production was estimated at 35 million metric tons (MT). The second largest producer, Malaysia, produces 21 million MT, and the third, Thailand, produces 2.3 million MT, only a small fraction of Indonesia. The phenomenal increase in production meant that the land area under oil palm cultivation during 1995-2016 expanded very significantly as well. This steady increase in area is shown in Figure 2. 


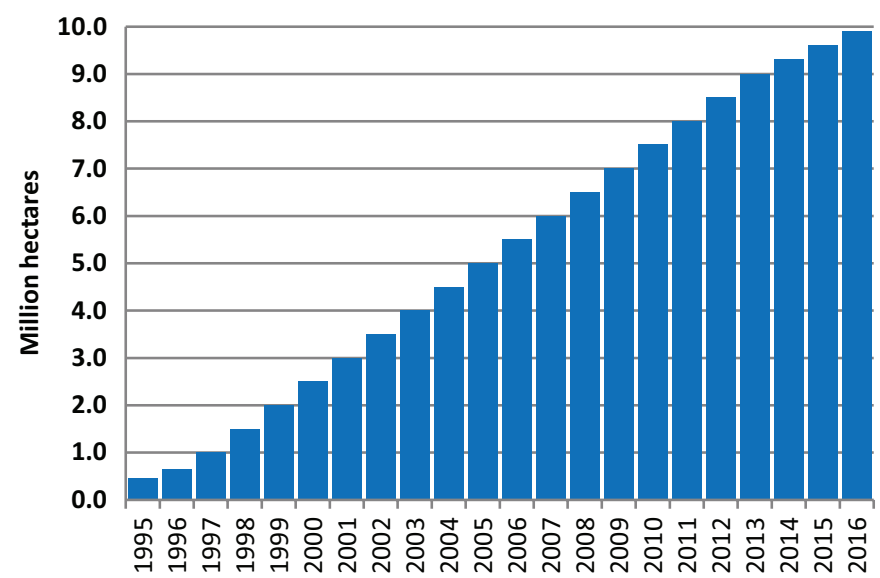

Figure 2. Indonesian Oil Palm Cultivated Areas, 1995-2016 Source: USDA (2015).

Under Yudhoyono's Presidency, palm oil production became one of the main pillars of economic development and poverty alleviation, especially for the rural areas. In 2008, just before he was elected President, smallholders accounted for nearly $40 \%$ of the land, some 1.2 million ha, where oil palm was cultivated. Some 3.5 million households, or about 15 million rural Indonesians, made a living out of growing oil palm. The number of people involved in palm oil supply chain activities (offfarm) was even greater. Thus, palm oil was already an important economic activity in the rural areas before he started his second term as the President.

The plan for agricultural expansion of oil palm was truly ambitious. It proposed to increase the cultivated area to $10-12$ million ha by 2020 . This would produce 40 million MT of crude palm oil. This expansion was expected to generate new employment opportunities for 1.3 million households. If so, it would reduce the total number of poor people by at least 5.2 million, from an estimated 30 million in 2009.

Favored by government policies, economics of production, commercial logic, and accelerating global demands, Indonesia overtook Malaysia as the world's largest commercial palm oil producer. The increase in palm oil production in Indonesia, during the 1964 to 2016 period, has been truly phenomenal. In 1964, Indonesia produced only 157,000 MT of palm oil. 


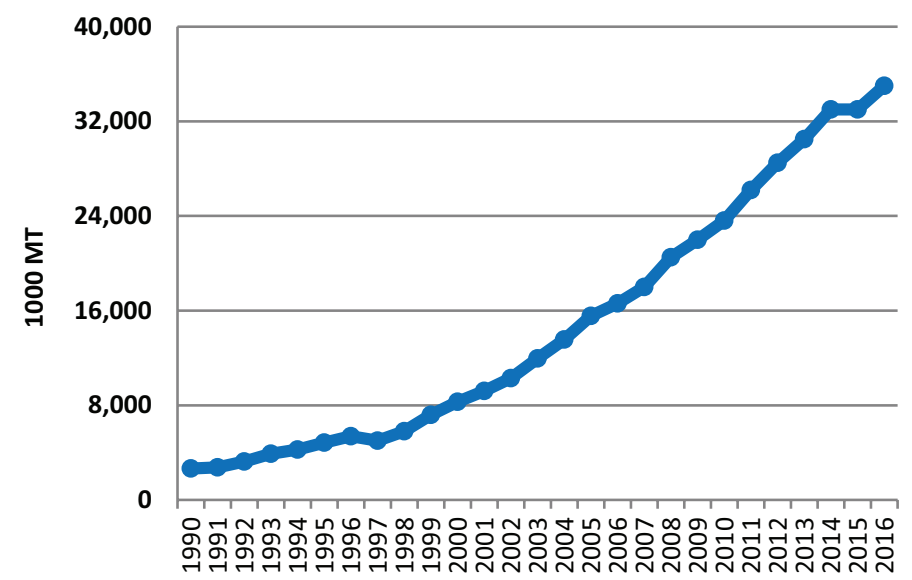

Figure 3. Indonesian Palm Oil Production

Source: Index Mundi (2016).

It increased to $752,000 \mathrm{MT}$ in 1980, to 2.65 million MT by 1990, $8.3 \mathrm{mil}-$ lion MT in 2000, 23.6 million MT in 2010 and 35.0 million MT by 2016. The growth in production is shown in Figure 3.

Not surprisingly this phenomenal growth in palm oil cultivation during the post-1990 period (Figure 3) has been possible due to an exponential increase in land areas where oil palm had been planted (Figure 2). During the 1995 to 2016 period alone, the area planted increased by some 20 times, and quantity produced by some eleven times. Viewed from any perspective, these growth statistics have been phenomenal.

\section{Implications of this growth}

The exponential increase in land area used for oil palm cultivation in Indonesia has been possible primarily through the clearance of primary and secondary forests and other vegetative growths. This of course is not new. As the population of Indonesia has increased, there has been progressive deforestation, so that enough land could be made available for all kinds of human activities, including agriculture. In Indonesia's case, the pressure on land clearance has been intense and sustained, especially during the last 50 years, because of oil palm, rubber and timber plantations. The problems have been further exacerbated by the absence of any 
reasonable land use planning and absence of good environmental policies and management practices.

The population pressure in Indonesia can be visualized from the following facts. In 1960, its population was 88.69 million. By 2015, it had increased to 255.46 million. In other words, in a period of only 55 years, its population increased by about three times. In $1960,85 \%$ of its population (75.38 million) lived in rural areas. By 2015, while this percentage had declined to $46 \%$, in absolute number its rural population was much higher (117.51 million) than what it was 50 years ago. An overwhelming percentage of the rural population still depends on agriculture to earn a living, and still live below the poverty line.

Spurred by steadily increasing global demands for palm oil, timber and rubber, Indonesia has progressively lost forest cover to agricultural development due to deliberate and intentional burning (Quah, 2002). Much of this forest loss has taken place in the lowlands of Sumatra and Kalimantan (Mayer, 2006). This region witnessed an annual deforestation rate of nearly $3.5 \%$ during the $1990 \mathrm{~s}$. Hansen et al. (2009) have estimated that between 1990 and 2005, this region lost nearly 40\% of its forest cover. Margono et al. (2014) have estimated that more than 6Mha of deforestation took place in Indonesia between 2001 and 2012. By 2012, deforestation in Indonesia exceeded that of Brazil.

Several recent analyses have found that the latest trend has been to move away from the clearance of dryland forests to secondary and peatland forests (Margono et al., 2014; Miettinen et al., 2011). Fire is used extensively to clear peatland and degraded forests. Herein lies the genesis of a major transboundary air pollution problem because of economic necessity of cultivating oil palm in Indonesia.

Peatland forests are generally protected by the presence of high water tables. In order to reclaim these lands for planting oil palm trees, water has to be drained so that vegetation growth can be cleared by fire. As the water table declines, forests and vegetation become increasingly susceptible to burning, as well as to oxidation. This burning has now become the primary source of national and transboundary air pollution. Oxidation does not have any perceptible impact on air quality.

Peatlands are major carbon sinks and can store up to 20 times more carbon dioxide compared to tropical rainforests on normal mineral soils. 
Thus, when they are burnt, they become major emitters of $\mathrm{CO}_{2}$ as well as other undesirable gaseous pollutants like $\mathrm{CO}, \mathrm{CH}_{4}, \mathrm{NO}_{\mathrm{x}}$ and $\mathrm{NH}_{3}$. Minister Zulkifli (2015) of Singapore noted during his speech at UNFCCC COP-21 meeting in Paris that peat fires, in 2015, in Indonesia, released over one giga-ton of $\mathrm{CO}_{2}$ into the atmosphere. These emissions, only over a few months, were higher than the total annual carbon emissions of a major industrialized country like Germany.

This burning, in addition to producing greenhouse gases, contributes to extensive generation of smoke, including particulate pollution, which in turn contributes to serious haze problems in Indonesia and neighboring countries every summer.

The direct linkages between the demand for plantation products, global economy and deforestation can be appreciated by the fact that deforestation rates were significantly lower during the economically lean years of 1999-2001. During this period, the demand for commodities like palm oil was not robust. As the global economy improved, demand increased, and prices of palm oil and other commodities firmed as well. This, in turn, increased the production of palm oil in Indonesia.

Traditionally, forests and degraded lands are mostly cleared by slashand-burn agriculture. This has been the normal practice in the country for centuries. The process is cheap, easy and does not require any technical skill or heavy machineries. The fire also helps to control pest. The ash and decomposition of organic matters improve soil fertility, at least over the short-term. Because of low costs, convenience and some perceived benefits, fire is widely used as an effective means to clear vegetative growth.

\section{Palm oil production and haze}

The forest clearance for agricultural activities takes place every year during the dry season between July and September. The smoke created by these forest fires not only engulfs the provinces where they originate, but also other Indonesian provinces and neighboring countries. During droughts and El Niño years, when the biomass is very dry and rainfall is scarce, the haze problems in Indonesia and neighboring countries become significantly worse. It should be noted that serious drought years are not necessarily El Niño years. 
During the 1970s and 1980s, the haze issue was neither serious nor extensive. In addition, the health, economic and environmental impacts were neither well-known nor serious enough so that the public and the policymakers were concerned (Koplitz et al., 2016). By 1995, however, the haze problem was deemed to have become a serious environmental and health issues over a large region, especially as it recurred each summer. This forced the ASEAN environment ministers to take up the issue of transboundary haze problems.

The particulate and gaseous emissions from extensive and intensive forest, vegetation and peat fires of 1997 were especially severe. It was an E1 Niño year when severe drought and dry vegetation conditions ensured that the land-clearing fires, once started, became uncontrollable. Liew et al. (1998) estimated the burned areas in Kalimantan and Sumatra based on SPOT images. This estimate showed that of actual burned area, 50\% came from agriculture and plantation, 30\% from forests and bushes and $20 \%$ from peat forests. These fires were an important source of particulate and gaseous emissions to the local, national and regional atmosphere. In fact, these fires contributed significantly to more particulate and gaseous emissions to the atmosphere compared to even the unprecedented Kuwaiti oil fire of 1991 (Levine, 1999) which was a major carbon emitter.

The continuation of haze every summer and the serious health and economic impacts of the 1997 haze galvanized all the neighboring countries of Indonesia into action. They were not only getting exasperated by the regular annual occurrence of haze but were also becoming increasingly aware of the health risks, initially of $\mathrm{PM}_{10}$ and a decade later of $\mathrm{PM}_{2.5}$. The media and social pressure on the governments of these countries to do something significant to reduce the extent and magnitude of the haze that originated from Indonesia became increasingly intense.

The neighboring governments took up the haze issue bilaterally with the Indonesian Government as well as multilaterally through the ASEAN. These discussions led to an Agreement on Transboundary Haze Pollution which was signed in Kuala Lumpur, on 10 June 2002 (http://haze.asean. org/asean-agreement-on-transboundary-haze-pollution/). The Agreement was ratified by sufficient number of countries to enter into force on 25 November 2003.

Even though the Agreement entered into force in late 2003, Indonesia was not a signatory to it for over a decade due to various political 
maneuvering (Biswas and Hartley, 2015). The Indonesian Parliament refused to endorse the Agreement. It was finally ratified more than a decade later, on 14 October 2014.

Although the ASEAN Agreement has been in force since 2003, and Indonesia finally ratified it in 2014, it does not appear to have had any perceptible effects in reducing the impacts of the 2015 haze. This was another bad year for serious transboundary haze. There are many reasons for this rather sad state of affairs.

The first set of reasons relate to the ASEAN haze treaty and its possible effectiveness in reducing haze. There is no question that all the ASEAN countries appreciate the adverse health, economic and environmental impacts of the transboundary haze. Equally, it is now firmly in their agenda as a priority issue to be tackled. While the ASEAN rhetoric has been strong, real actions on the ground thus far have been minimal. In the consensus-driven world of the ASEAN, with a strong history of nonintervention in the affairs of member countries, finding an effective and implementable solution for a transboundary issue like the haze has caught the Association flat-footed.

The problem has been exacerbated by the fact that under the ASEAN protocol, any assistance to a country can only be by unanimous consent and this must have the agreement of the recipient state. Indonesia has consistently denied most offers of assistance, probably because of sovereignty reasons as well as political and reputational implications within and outside the country and national pride. Furthermore, the Agreement may be legally binding but it has no enforceability, accountability, or any mechanism for independent monitoring, sanctions on the offending countries, or even dispute settlement procedures. The Agreement can only be effective if all the 10 countries concurrently and voluntarily take all the necessary measures to reduce haze. This is somewhat unlikely and often an unrealistic expectation.

The second set of reasons has to do with Indonesia directly. The country faces serious challenges and constraints to reducing haze. Among these are the following:

- Magnitude and extent of the problem - Given the vast area of the country, its archipelagic nature, sheer size and extent of forest areas, number of states involved from where fire originates, and immense 
number of parties involved in palm oil cultivation, any objective and realistic analysis will indicate that the problem cannot be solved over the short-term. The current situation has developed over decades, promoted by proactive palm oil production policies and strategies of the government and international institutions. These policies never seriously considered the potential environment health and social impacts of increasing palm oil production. It will be years before the situation can be brought fully under control.

- Centre-state-municipal relations - The ASEAN Agreement was eventually ratified by the Central Government of Indonesia, but land use, forest management, agriculture, etc., are state subjects on which the center has at best limited say or control. In addition, some of the issues are under the jurisdiction of the municipal governments over which neither the central nor state government institutions have much control.

- Appropriate policies of different institutions at three government levels - Effective haze management requires coherent policies at all the three governmental levels. Such cohesion is simply absent at present. Even at the Federal level, good collaboration and coordination will be necessary between departments and ministries like land, water, environment, agriculture, industry, commerce and law, all of which have a say in certain aspects of haze management. Even all developed countries, let alone a developing country like Indonesia, have found it very difficult to have such a coordinated policy approach on a multi-sectoral and multi-issue problem. To get all the institutions, at all the three levels, in many different states, marching towards the same policy goals, at reasonably similar speeds, will be a herculean, if not an impossible, task under the best of circumstances.

- Institutional capacities - Adequate technical, managerial, administrative, financial, legal and regulatory capacities (Atkinson, 2014) at all the three levels leave much to be desired. It will take some time before such effective capacities can be developed.

- Corruption - This is endemic at all the three levels of the government. It will be extremely difficult to reduce it significantly in the foreseeable future so that significant reductions in haze can be observed. 
- Powerful interests - While haze is a serious problem in Indonesia and its neighboring countries, for farmers and industries, burning continues to be the simplest and the cheapest method to clear the vegetation. Weaning them from such practices will require the development of newer and economic ways to clear forest and vegetation growth, monitoring of prevalent situations, enforcement of laws and regulations and massive education and public awareness programs on the severe economic, environmental, health and social impacts of haze, both within and outside the region from where fire originates. All of these are mostly missing at present.

- Pervasive poverty - For millions of poor and small-scale rural farmers, burning has been the traditional way to clear land to produce palm oil. Their livelihoods depend on this practice. For any democracy, where candidates depend on the votes of rural farmers to get elected, it will be a very difficult political choice to ask this group to use an alternative methods of vegetation clearance which are more expensive and complex. The issue of how to provide the rural farmers the means to earn sustainable livelihoods and alleviate their levels of poverty have been mostly missed by Western scholars and development experts. Effective and economic ways have to be found for these poor rural farmers if the incidence of haze has to be substantially reduced.

Given all the constraints and challenges faced by Indonesia, it is highly unlikely that the haze situation can be significantly reduced before 2025 at the earliest. The roadmap that the ASEAN countries adopted in Kuala Lumpur, in August 2016, to achieve a haze-free ASEAN zone by 2020 will most likely prove to be a pipe-dream.

Indonesia is the main emitter of the smoke. Thus, most of the important decisions to control smoke have to be taken by the Indonesian Government at all the three levels. These policies then have to be implemented within a reasonable period of time so that the ASEAN region could become a haze-free zone over the long term. This objective, laudable though it is, is neither realistic nor achievable. In fact, even at the time of writing this contribution in August 2016, a realistic set of implementable policies that can substantially reduce smoke emissions from Indonesia 
by 2020 does not even exist, let alone consideration of their potential implementation.

Tellingly, the Indonesian Minister for Environment and Natural Resources, Siti Nurbaya Bakar, was not even present at the ASEAN meeting in Kuala Lumpur in August 2016, ostensibly because she was occupied with a conservation meeting in Bali. This was the second year in a row that the Minister had missed the meeting of the ASEAN Environment Ministers. Under such political conditions, it is difficult to be hopeful. It does not convey the right message in terms of commitment, given her earlier combative responses to Singapore's concerns on transboundary haze. For example, in October 2015, she said: "I would respectfully ask them (Singaporean neighbors) to stop making so many comments, particularly when it comes to the fires and haze-related issues." (Must Share News, http://mustsharenews.com/indonesian-minister-haze/).

In addition, in early 2014, the Indonesia Vice-President, Jusuf Kalla, said, "For 11 months, they (our neighbors) enjoyed nice air from Indonesia and they never thanked us. They have suffered because of the haze for one month and they get upset" (Jakarta Globe, http://jakartaglobe.beritasatu. com/news/vp-kalla-slams-neighboring-countries-over-haze-complaints/). He also said that the haze that affected Malaysia and Singapore was blown there by wind, over which Indonesia has no control. Thus, the mindsets at high political levels need to substantially change for effective haze management.

It is thus difficult to be optimistic that the transboundary haze can be controlled reasonably well by 2020 , let alone transforming the region into a haze-free zone.

\section{Way ahead}

There is no question that over the last five decades the problem of transboundary air pollution due to the Southeast Asian haze has become progressively more serious. During the 1960s and the 1970s, the problem did exist. However, it was minor and thus did not receive much attention in the countries that were affected by it. It was neither a political nor a social issue, and did not attract any serious political, public or media attention.

The situation started to change in the late 1980s, and by the first half of the 1990s, transboundary haze problems could no longer be ignored. As 
the area under palm oil dramatically increased during the 1990s and the post-2000 periods, it became an important public policy issue in Malaysia and Singapore. The environmental, economic and health impacts of the transboundary haze are now very serious, and have also become important political, public and media concerns. These cannot longer be ignored.

Indonesia is the country which suffers the most from the haze. It is also the country which benefits the most because of the palm oil production. The benefits it brings to the country in terms of export earning, employment generation and providing livelihoods for millions of its households are substantial. In contrast, countries like Singapore and Malaysia receive no benefits but pay heavy costs due to a haze that originates in another country on which they have only a limited say and virtually no control.

Because of the lopsided distribution of benefits and costs, views and perspectives of Indonesia and the haze-affected countries have often been different (Biswas \& Tortajada, 2016). Harsh words have been exchanged in recent years between the politicians of the concerned countries. This antagonism and frustration, though understandable, is unlikely to improve the situation.

Any lasting and long-term solution will have to start with the fact that Indonesia will not only have to continue with the production of palm oil in the future but also may have to increase it substantially. Politically and economically, it has few other viable alternatives to maintain and generate additional employment in rural areas and palm oil supply chain activities for its steadily increasing population.

Future solutions involving expanding palm oil production, while significantly reducing current haze levels in Indonesia and its neighboring countries, will lie on where the expansion takes place and how well the production processes are managed in terms of their environmental footprints, especially in terms of generation of smoke, based on the best available knowledge and information. For example, estimates by Marlier et al. (2015) indicate that if the peatland in Sumatra and Kalimantan can be properly protected, it could reduce future emissions by some $60 \%$ compared to current practices. This could reduce smoke concentration levels by a factor of three in Singapore.

Similarly, if the current moratorium on new concessions in peatland and primary forests can be maintained, it could reduce emissions by $10 \%$. 
Another 35\% reduction will be possible by limiting expansions on all peat and forest lands (Austin et al., 2015).

Thus, solutions do exist which could enable Indonesia to expand its palm oil production significantly up to 2050 , and concurrently reduce smoke generation very substantially. This would require that future expansions be carefully planned and managed which would enable the country to double its palm oil production while reducing the existing levels of transboundary haze. This two-prong policy strategy is most certainly achievable and will benefit both Indonesia and its neighbors.

In order to make progress in solving this complex and recurring annual challenge, it is imperative that the Indonesian public and policymakers be convinced beyond doubt that haze is bad for them. This will require credible and objective evidence. Even though the haze has been around for decades, no reliable estimates are currently available as to the costs to Indonesia in terms of health, loss of productivity or impacts on foreign direct investments. Foreign investors may decide to avoid the country for concerns not only with macroeconomic conditions, inadequate infrastructure, effectiveness of legal systems and traffic congestions but also because of extensive air and water pollution. A young and expanding population means the country will have to generate hundreds of thousands of new and well-paid jobs each year. This will require sustained FDI inflows. This effort will be seriously compromised unless environmental and economic conditions are substantially improved. External political pressures alone to address such concerns will be limited without greater public awareness of the problems in Indonesia (Biswas and Hartley, 2015).

The policy battlefield needs to move from the banquet tables of regional summits to the hearts and minds of the Indonesians. Winning their support for stricter regulations and enforcement is a bipartite strategy. First, an effort must be made to gather data and generate robust evidence about the domestic health, economic and environmental impacts of Indonesian haze. Second, the findings must be expressed in an easily understandable way and disseminated widely through the media and other conduits. This should not be a one-off publicity effort, but a sustained awareness initiative that targets the general public and enlists the support of advocacy groups, NGOs, and ultimately (through domestic political pressure) government officials (Herawati and Santoso, 2011). 
Public understanding of the haze crisis in Indonesia should be as common as basic literacy, and at least as embedded as the public's knowledge of common health and safety issues related to smoking, pesticides and sanitation (Biswas and Hartley, 2015). This may not produce the instant solution that many believe would result from aggressive diplomatic actions like boycotts and sanctions. Haze mitigation interventions would be far more durable across political cycles because increased awareness often leads to deeply rooted interest in a policy issue. Indeed, an educated Indonesian public may prove to be the most powerful force for change needed to manage the haze effectively in the coming decades.

\section{References}

Atkinson, C. L. (2014). Deforestation and transboundary haze in Indonesia: Path dependence and elite influences, Environment and Urbanization Asia, 5(2): 253-267.

Austin, K. G., Kasibhatla, P. S., Urban, D. L., Stolle, F. and Vincent, J. (2015). Reconciling oil palm expansion and climate change mitigation in Kalimantan, Indonesia, PLoS ONE, 10(5): e0127963. DOI: 10.1371/journal.pone. 0127963

Biswas, A. K. and Hartley, K. (2015, September 21). Singapore haze: A new strategy needed. The Diplomat. Retrieved from http://thediplomat. com/2015/09/singapore-haze-a-new-strategy-needed/

Biswas, A. K. and Hartley, K. (2015, September 21). To tackle haze, win over the Indonesian public. Straits Times, Singapore.

Biswas, A. K. and Tortajada, C. (2013, August 25). Tackling haze: Learn from the Swedes. Straits Times, Singapore.

Biswas, A. K. and Tortajada, C. (2016, August 25). Raise public understanding in Indonesia to tackle haze. Business Times, Singapore.

Hansen, M. C., Stehman, S. V., Potapov, P. V., Arunarwati, B., Stolle, F. and Pittman, K. (2009). Quantifying changes in the rates of forest clearing in Indonesia from 1990 to 2005 using remotely sensed data sets, Environmental Research Letters, 4(3): 1-12.

Herawati, H. and Santoso, H. (2011). Tropical forest susceptibility to and risk of fire under changing climate: A review of fire nature, policy and institutions in Indonesia, Forest Policy and Economics, 13(4): 227-233.

Koplitz, S. N., Mickley, L. J., Marlier, M. E., Buonocore, J. J., Kim, P. S., Liu, T., Sulprizio, M. P., DeFries, R. S., Jacob, D. J., Schwartz, J. and Myers, S. S. 
(2016). Public health impacts of the severe haze in equatorial Asia in September - October 2015: A new tool for fire management to reduce downwind smoke exposure in the future, Environmental Research Letters (in review).

Levine, J. S. (1999). The 1997 fires in Kalimantan and Sumatra, Indonesia: Gaseous and particulate emissions, Geophysical Research Letters, 26(7): 815-818.

Margono, B. A., Potapov, P. V., Turubanova, S., Stolle, F. and Hansen, M. C. (2014). Primary forest cover loss in Indonesia over 2000-2012, Nature Climate Change, 4: 730-735.

Marlier, M. E., DeFries, R. S., Kim, P. S., Koplitz, S. N., Jacob, D. J., Mickley, L. J. and Myers, S. S. (2015). Fire emissions and regional air quality impacts from fires in oil palm, timber, and logging concessions in Indonesia, Environmental Research Letters, 10(8), 085005.

Mayer, J. (2006). Transboundary perspectives on managing Indonesia's fires, Journal of Environment and Development, 15(2): 202-223.

Miettinen, J., Shi, C. and Liew, S. C. (2011). Deforestation rates in insular Southeast Asia between 2000 and 2010, Global Change Biology, 17(7): 2261-2270.

Quah, E. (2002). Transboundary pollution in Southeast Asia: The Indonesian fires, World Development, 30(3): 429-441.

Zulkifli, M. (2015, December 7). National statement of Singapore to UNFCCC COP-21 meeting, Paris. Ministry for the Environment and Water Resources, Singapore. 